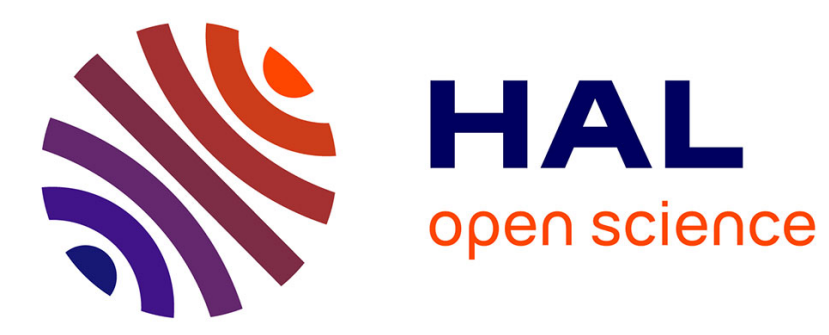

\title{
Production of electrolytic iron from red mud in alkaline media
}

\author{
Abdoulaye Maihatchi Ahamed, Marie-Noëlle Pons, Quentin Ricoux, Frederic \\ Goettmann, François Lapicque
}

\section{- To cite this version:}

Abdoulaye Maihatchi Ahamed, Marie-Noëlle Pons, Quentin Ricoux, Frederic Goettmann, François Lapicque. Production of electrolytic iron from red mud in alkaline media. Journal of Environmental Management, 2020, 266, pp.110547. 10.1016/j.jenvman.2020.110547 . hal-02892131

\section{HAL Id: hal-02892131 \\ https://hal.univ-lorraine.fr/hal-02892131}

Submitted on 7 Jul 2020

HAL is a multi-disciplinary open access archive for the deposit and dissemination of scientific research documents, whether they are published or not. The documents may come from teaching and research institutions in France or abroad, or from public or private research centers.
L'archive ouverte pluridisciplinaire HAL, est destinée au dépôt et à la diffusion de documents scientifiques de niveau recherche, publiés ou non, émanant des établissements d'enseignement et de recherche français ou étrangers, des laboratoires publics ou privés. 


\title{
Production of electrolytic iron from red mud in alkaline media
}

Abdoulaye Maihatchi ${ }^{1,2}$, Marie-Noëlle Pons ${ }^{2}$, Quentin Ricoux ${ }^{1}$, Frédéric Goettmann ${ }^{1}$, François Lapicque $^{2, *}$

${ }^{1}$ Extracthive, Centre CEA Marcoule, Bât. 51, 30591 Bagnols-sur-Cèze, France

${ }^{2}$ LRGP, UMR 7274, CNRS - Université de Lorraine, 1 rue Grandville, 54000 Nancy, France

*E-mail: francois.lapicque@univ-lorraine.fr

\begin{abstract}
$\underline{\text { Abstract }}$
In this study, the feasibility of producing electrolytic iron from red muds in a strongly alkaline medium at $110{ }^{\circ} \mathrm{C}$ was studied. The red mud samples from a French industry were characterized by various techniques (ICP-AES, SEM, XRD) to determine their chemical and mineralogical compositions. The main phase in the red mud investigated was hematite $\left(\alpha-\mathrm{Fe}_{2} \mathrm{O}_{3}\right)$. Iron electrodeposition tests from red mud suspended in a $12.5 \mathrm{~mol} / \mathrm{L} \mathrm{NaOH}$ electrolyte were conducted at constant current in a stirred electrochemical cell. The solid:liquid ratio and amounts of impurities contained in red mud were varied to optimize the faradaic yield and the production rate of electrolytic iron. Whereas hematite can be reduced to iron with a current efficiency over $80 \%$ for a current density (cd) up to $1000 \mathrm{~A} / \mathrm{m}^{2}$, the current efficiency with red muds was highest for a cd below $50 \mathrm{~A} / \mathrm{m}^{2}$ and then decreased regularly to $20 \%$ at $1000 \mathrm{~A} / \mathrm{m}^{2}$. In all cases, the deposit produced contained more than $97 \%$ metal iron. The moderate performance of the process investigated with red mud was attributed to a troublesome adsorption of red mud particles on the cathode, making the reduction far less efficient than that with hematite.
\end{abstract}

Keywords: Alumina; Red mud; Beneficiation; Iron electrodeposition; Hematite 


\section{Introduction}

Alumina is a very important mineral employed in several industrial fields, e.g., manufacture of aluminum metal, production of abrasive, refractory materials and electrical insulation. Unfortunately, primary deposits of pure alumina are extremely scarce, and it is estimated that more than $90 \%$ of the world's alumina production relies on bauxite ore via the Bayer process (Bayer, 1888). This process consists of hot alkaline leaching of the bauxite concentrates in order to selectively leach sodium aluminate. The world's largest aluminum producers of bauxite ore are China (51\%), North America (13\%), the Commonwealth of Independent States $(9 \%)$ and the Middle East (Senyuta et al., 2016). The insoluble residues of the Bayer process are called red muds. The management of this waste remains complex because of the difficulty of finding applications to profitably reuse residues that are alkaline, wet and can contain toxic metals. Therefore, red muds are usually discharged to seawater, landfilled as dry product with the risk of toxic compounds fly away or lagooned /disposed of into reservoirs as suspensions, with an important risk of breaking reservoir dams, as already happened at the Ajka factory in Hungary (2010) and in Brazil (2015) (Mayes et al., 2016). To prevent this from happening again, studies have been conducted to stabilize red mud landfill (Li et al., 2018), but these have unfortunately not led to industrial implementation. Currently, it is estimated that approximately 70 million tons of red muds are produced and stored yearly worldwide. The main components of these red muds are $\mathrm{Fe}, \mathrm{Al}, \mathrm{Si}, \mathrm{Ti}, \mathrm{Na}$ and $\mathrm{Ca}$, together with a large number of minor elements such as $\mathrm{V}, \mathrm{Cr}, \mathrm{Zr}$ or $\mathrm{Nb}$, but as seen in Table $\mathrm{S} 1$ (Supplementary Materials), the chemical composition of red muds can vary with their origin.

Numerous studies have been conducted to identify sustainable ways to recycle/reemploy red muds. First, iron and aluminum can be extracted from red muds in a process involving (Li et al., 2016):

(i) roasting the red muds using coal as a reducing agent, (ii) magnetic separation to extract iron 
oxides, and (iii) leaching of the nonmagnetic part to recover aluminum. Addition of sodium carbonates has been reported to increase the yield of hematite (Béchara et al., 2018). Red muds can also be used to produce pig iron by an addition of carbon powder at $1200-1500{ }^{\circ} \mathrm{C}$ (Raspopov et al., 2013), but impurities, e.g., sulfur and silicates, were also present in the final product. Red muds can also be added at $5 \%$ to cement to produce building materials exhibiting the same mechanical properties as conventional cement (Vangelatos et al., 2009). Other works on red muds suggest using these residues as adsorbents for pollutants contained in wastewater, e.g., phosphate (Liu et al., 2007; Cusack et al., 2019), arsenic (Soner Altundoğan et al., 2000; Mohan and Pittman, 2007; White et al., 2013; Rubinos and Spagnoli, 2019), chromium (Pradhan et al., 1999; Li et al., 2015), cadmium (Gupta and Sharma, 2002; Ju et al., 2012), and nickel (Zouboulis and Kydros, 1993). However, in spite of the diversity of the proposed applications, only $15 \%$ of red mud produced yearly can be reused or recycled (Guo et al., 2013).

In this context, we propose an alternative route to beneficiate red muds in an electrochemical process. The process consists of directly reducing iron species, initially present in red muds as hematite, to metal. For this purpose, the present investigation relies on the results of previously published works on the production of electrolytic iron from hematite in a highly alkaline medium (18 M NaOH) (Allanore et al., 2008, 2010; Yuan and Haarberg, 2009; Gu et al., 2014; Feynerol et al., 2017) at $110^{\circ} \mathrm{C}$. These pioneering works were motivated by the possible reduction in carbon footprint produced in steelmaking, currently near 1.8 ton $\mathrm{CO}_{2}$ per ton iron or steel (Feynerol et al. 2017). Moreover, the above studies could also highlight the particular deposition of iron from hot alkaline suspensions of hematite, with faradaic yield over $80 \%$ at 1000 A.m ${ }^{-2}$ (Allanore et al., 2008, 2010; Yuan and Haarberg, 2009, Gu et al., 2014). Because of the very low solubility of Fe(III) species in alkaline media, iron deposition cannot be due only to the electrode reduction of dissolved $\mathrm{Fe}(\mathrm{III})$, as in most electrodeposition processes. In contrast, it was shown that iron deposition 
efficiently proceeds by the intermediate formation of a magnetite layer on the hematite particles in contact with the cathode, followed by further reduction via divalent iron species (Allanore et al., 2007a, 2008, 2010; Yuan and Haarberg, 2009; Gu et al., 2014; Feynerol et al., 2017). The high faradaic yield of iron coupled to cell voltages below $2 \mathrm{~V}$, corresponds to an energy consumption below $4 \mathrm{MWh} /$ ton iron/steel from iron ores $(2.4 \mathrm{MWh} /$ ton in the electrolytic cell), in comparison to approx. $5 \mathrm{MWh} /$ ton in regular high furnaces. The market price of carbon steel is currenty approx. US\$ 700/ton (Worldsteelprices.com). Considering the cost of electricity, in the order of US\$ $0.15 / \mathrm{kWh}$, the above energy demand of steel production nearly corresponds to the value of the steel produced. However, although being not directly economically competitive at present time, the route still under development by steel manufacturers, can be viewed as a promising alternative route to high furnaces, with far lower $\mathrm{CO}_{2}$ emissions.

The aim of this preliminary study is to examine the possibility of transferring the knowledge gathered in the quoted studies on electrolytic reduction of hematite to the more complex case of red mud beneficiation. To our knowledge, no scientific works have been published on the production of electrolytic iron from red mud. Yet, these residues are a real source of iron in the form of oxides or hydroxides. In addition to allowing iron beneficiation, with reduced $\mathrm{CO}_{2}$ emissions, expected advantages of this approach are mainly to reduce the volume of final waste to be disposed: the urgency of the current situation in Al-producing countries was an incentive to explore new routes in view to limiting the growing amount of red muds disposed. Moreover, the alkali content of the red mud is to reduce the $\mathrm{NaOH}$ concentration to be added to the electrolytic solution, in comparison to the reference case of hematite.

The feasibility of electrolytic iron production has been studied on samples of red mud from a European alumina producer. These samples as well as electrolytic iron samples, have been characterized by cross-linked techniques, e.g., XRD, SEM, and ICP-AES. Commercial hematite 
has also been used in parallel with the red mud for a comparison of the faradaic yield and of the deposit quality, and for a better understanding of iron electrodeposition process from red muds.

\section{Experimental section}

\subsection{Cell and electrodes}

The electrochemical cell (Figure 1) used in this study was a double-walled Pyrex ${ }^{\mathrm{TM}}$ cell with a total volume of $600 \mathrm{~mL}$ and a diameter of $80 \mathrm{~mm}$. For most experiments, approximately $450 \mathrm{~mL}$ of 12.5 mol. $\mathrm{L}^{-1} \mathrm{NaOH}$ solution and $150 \mathrm{~g}$ of red mud were introduced into the cell. The temperature of the electrolytic suspension was maintained at $110{ }^{\circ} \mathrm{C}$ by circulation of oil in the jacket. The reactor was fitted with a three-electrode system. The electrode materials were chosen based on previous work (Feynerol et al. 2017). The working electrode was a cylindrical graphite rod (Graphitech, France) with a wetted area of $19.4 \mathrm{~cm}^{2}$. The surface of the cathode was polished with fine sandpaper $(80 \mu \mathrm{m})$, washed with $1 \mathrm{~mol} . \mathrm{L}^{-1}$ of hydrochloric acid solution, then rinsed with deionized water and dried in air. A platinum-coated titanium grid (AMPER Industrie, France) was used as a counter electrode. The grid with an area of $122 \mathrm{~cm}^{2}$ formed a cylinder around the cathode. A saturated $\mathrm{Ag} / \mathrm{AgCl}$ electrode (VWR, France) was used as the reference electrode $(\mathrm{E}=0.210 \mathrm{~V}$ vs. NHE at $\left.25^{\circ} \mathrm{C}\right)$. The suspension was stirred at $400 \mathrm{rpm}$ by a Teflon-coated magnetic bar $(60 \mathrm{~mm}$ long and $9 \mathrm{~mm}$ in diameter). A SP-150 potentiostat coupled to a 10 A booster (BIOLOGIC SAS, France) acted as the current source. 


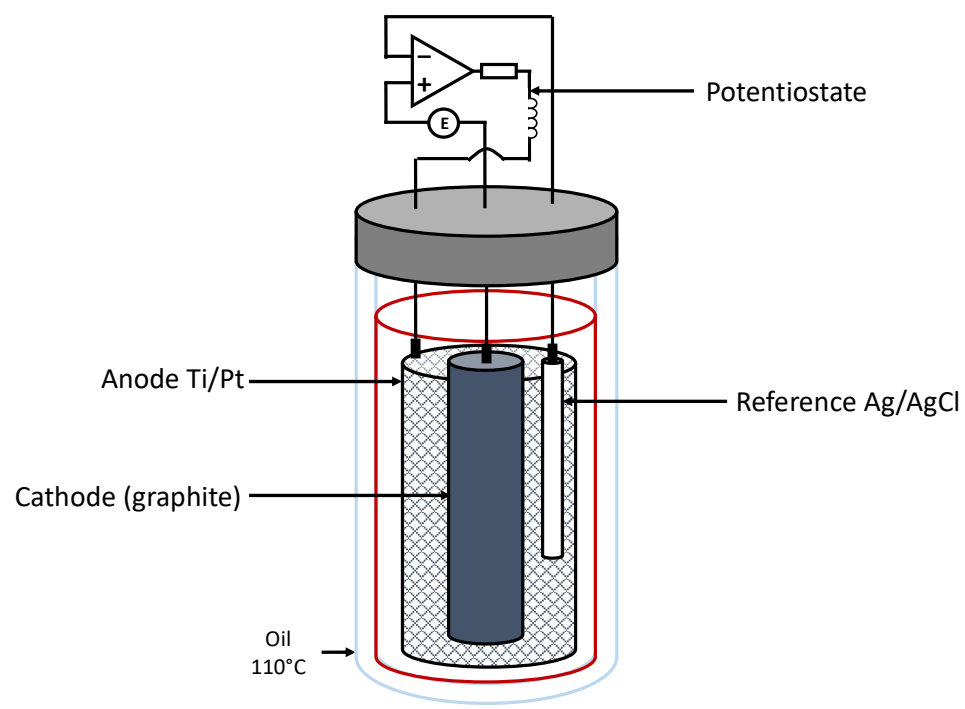

Figure 1: Electrochemical cell

\subsection{Calculation of faradaic yield}

Assuming that all the electrons exchanged are used for the deposition of iron, the theoretical mass amount of metal $\mathrm{m}_{\mathrm{Fe} \text {,theor }}$ can be calculated using Faraday's law:

$\mathrm{m}_{\mathrm{Fe}, \text { theor }}=\frac{\mathrm{M}_{\mathrm{Fe} \cdot \mathrm{I} \cdot \Delta \mathrm{t}}}{\mathrm{n} \cdot \mathrm{F}}$

where $\mathrm{M}_{\mathrm{Fe}}$ is the molar weight of the metal $\left(55.85 \mathrm{~g} \cdot \mathrm{mol}^{-1}\right)$, I is the current, $\Delta \mathrm{t}$ is the duration of the experiment, $\mathrm{n}$ is the number of electrons involved and $\mathrm{F}$ is the Faraday constant $\left(\mathrm{C} \cdot \mathrm{mol}^{-1}\right)$. The faradaic yield was determined by dividing the mass of the deposit - estimated by weighing the cathode after and before the tests - by $\mathrm{m}_{\mathrm{Fe} \text {,theor }}$.

Faradaic yield $(\%)=\frac{\text { Deposit mass }}{\mathrm{m}_{\mathrm{Me} \text {,theor }}} * 100$.

Relation (2) relies under the assumption that the deposits consist of pure iron: the assumption has been carefully checked, as presented in Section 3.3. Besides, for deposit amounts below $50 \mathrm{mg}$, the uncertainty in the faradaic yield has been estimated at $10 \%$, whereas it was only at $3 \%$ for deposits over $1 \mathrm{~g}$, and at $5 \%$ in other cases. Moreover, approx. $50 \%$ of the tests have been replicated, the 
deviation between the replicate results obtained, could validate the estimated ${ }^{2}$ error, in addition to the trends observed.

\subsection{Chemical reagents}

A red mud sample was obtained from Alteo, a European manufacturer specialized in alumina production. Pure hematite $\left(98 \%\right.$, VWR, France) was also used for comparison. A 12.5 mol.L ${ }^{-1}$ $\mathrm{NaOH}$ solution was prepared by dissolving sodium hydroxide pellets (purity 98\%, VWR, France) in deionized water. The hydrochloric acid solution $\left(1\right.$ mol. $\left.\mathrm{L}^{-1}\right)$ used to clean the electrodes was prepared from $37 \%$ hydrochloric acid (VWR, France). In most experiments, the suspensions were prepared by adding the required amount of red mud to the $\mathrm{NaOH}$ solution to obtain a solid:liquid ratio of $1 / 3 \mathrm{~g} / \mathrm{mL}$. Hematite (pure grade) was a VWR product. At the end of each test, the cathode was dismantled from its support and then rinsed thoroughly with deionized water, before drying at $60^{\circ} \mathrm{C}$. Once dried, the cathode was weighed to determine the mass of the deposit. Subsequently, the deposit was detached from the cathode substrate for SEM observation and characterization. Chemical composition of the deposit was obtained by inductively coupled plasma atomic emission spectroscopy (ICP-AES) of the solution recovered after dissolution of the deposit sample in hydrochloric acid, whereas its structure was identified by X-ray diffraction.

\subsection{Characterization of minerals}

The analysis and characterization of red mud are described in the Supplementary Material section. Properties of the hematite (VWR) used for comparative tests were also reported there. Results of these investigations i.e. chemical composition, XRD spectra, particle size distribution and apparent viscosity of the suspension, are presented there. 


\section{Results and discussion}

\subsection{Electrochemical behavior of the red mud and hematite species in alkaline media}

To compare the electrochemical behavior of red mud to that of commercial hematite, cyclic voltammetry was carried out between -1.5 and $-0 \mathrm{~V}$ vs. $\mathrm{Ag} / \mathrm{AgCl}$ at $40 \mathrm{mV} \cdot \mathrm{s}^{-1}$ : for better visualization, the variations of the current density in Figure 2 are in the restricted domain $-1.5 /-$ 1.0 V vs. $\mathrm{Ag} / \mathrm{AgCl}$ (Figure 2). The curves provide orders of magnitude for the cathode current density and the potential of the reactions considered. Hematite present in the two minerals investigated, dissolves in alkaline media as shown in reaction (3).

$$
\mathrm{Fe}_{2} \mathrm{O}_{3}+3 \mathrm{H}_{2} \mathrm{O}+2 \mathrm{OH}^{-} \rightarrow 2 \mathrm{Fe}(\mathrm{OH})_{4}^{-}
$$

The solubility of trivalent iron in this medium was reported at $2.6 \times 10^{-3} \mathrm{~mol} . \mathrm{L}^{-1}$ (Allanore et al., 2007a). As reported in previous papers (Allanore et al., 2007b, 2008,2010, 2010; Zhang et al., 2017), the electrochemical reduction of trivalent iron oxide consists of two reduction processes in parallel: (i) reduction of ferric $\mathrm{Fe}(\mathrm{OH})_{4}{ }^{-}$ions and (ii) reduction of hematite particles in contact with the cathode surface to magnetite, then to iron.

The cyclic voltammetry curves with both mineral fractions show the presence of several reduction peaks, mainly for potentials more cathodic than $-1.2 \mathrm{~V}$ vs. $\mathrm{Ag} / \mathrm{AgCl}$. These curves have been interpreted on the basis of former papers (Allanore 2007a, 2008). It can be observed that the current recorded with red mud are significantly smaller than those with commercial hematite. 


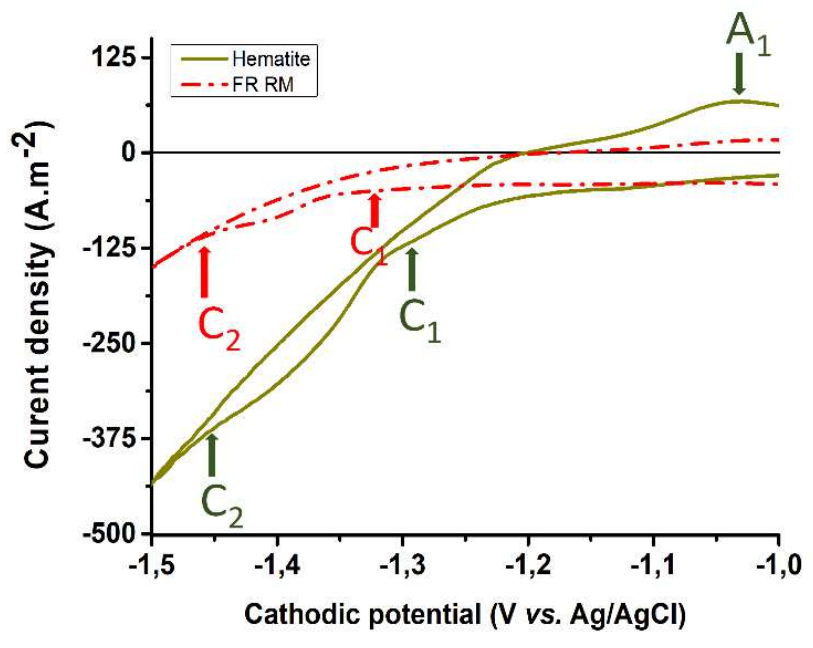

Figure 2: Cyclic voltammetry on red muds and hematite suspensions in $12.5 \mathrm{~mol} \cdot \mathrm{L}^{-1} \mathrm{NaOH}$ at $110^{\circ} \mathrm{C}$, sweep rate $=40 \mathrm{mV} \cdot \mathrm{s}^{-1}$.

In the cathodic part of the curves, point $\mathrm{C}_{1}$ observable near $-1.28 \mathrm{~V}$ and $-1.32 \mathrm{~V}$ vs. $\mathrm{Ag} / \mathrm{AgCl}$ with hematite and red mud particles might correspond to the reduction of $\mathrm{Fe}(\mathrm{OH})_{4}^{-}$ions to $\mathrm{Fe}(\mathrm{OH})_{3}^{-}$ species. The better-defined feature, $\mathrm{C}_{2}$ near $-1.43 \mathrm{~V}$ for hematite and the red mud, was attributed to the reduction of intermediate magnetite to iron metal, and the large rise of cathodic current from $-1.45 \mathrm{~V}$ corresponds to both iron deposition and hydrogen evolution. Finally, the anodic peak (A1) near $-1.05 \mathrm{~V}$ expresses the occurrence of dissolution of the iron deposited or the oxidation of intermediate divalent iron to $\mathrm{Fe}(\mathrm{OH})_{4}^{-}$species.

The above qualitative information is not sufficient to fully characterize the potential of both electrochemical depositions, thus electrodeposition experiments were carried out at a constant current, with monitoring of cell voltage and cathode potential, to follow the effect of current density and other operating conditions on the faradaic yield. 


\subsection{Influence of operating parameters on the faradaic yield}

\subsubsection{Influence of current density on red mud electrolysis}

Current density (cd) is an important factor in electrochemical processes since it governs the production rate, depending on the faradaic yield. To determine the optimal current density for iron electrodeposition from red muds, several tests were performed at $110{ }^{\circ} \mathrm{C}$ with a solid/liquid ratio of $1 / 3 \mathrm{~g} / \mathrm{mL}$. As shown in Figure $3 \mathrm{a}$, the faradaic efficiency of reducing red mud particles to electrolytic iron depends on the cd level. At a very low current density $\left(25 \mathrm{~A}^{-2} \mathrm{~m}^{-2}\right)$, the faradaic efficiency was found to be near $41 \%$. When the cd was set at $41 \mathrm{~A} \cdot \mathrm{m}^{-2}$, the efficiency increased to $72 \%$. On the other hand, for a larger current density, the faradaic yield regularly decreased to only

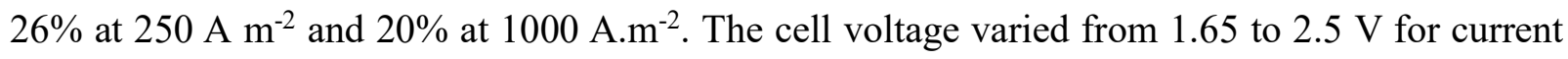
density varying from 41 to $1000 \mathrm{~A} \cdot \mathrm{m}^{-2}$. Corresponding energy demand in the electrolytic cell was estimated to be in the range $6.1-12 \mathrm{MWh} / \mathrm{t}$. For comparison, the faradaic efficiency for hematite reduction remains high, approximately $80-85 \%$ at the three cd levels considered (Figure $3 \mathrm{~b}$ ), the cell voltage was below $2.4 \mathrm{~V}$, then the energy demand in the lab electrolytic cell was below 2.9 $\mathrm{MWh} / \mathrm{ton}$, in fair agreement with values formerly reported.

Iron production from electrolytic treatment of red mud appears a poorly efficient process. These disappointing results are presumably linked to the current density presented in Figure 1, far lower with red mud than with commercial hematite. The cause of the poor efficiency with red mud may be due to the larger suspension viscosity, found at $7 \mathrm{cP}$ at $110^{\circ} \mathrm{C}$, but only at $2.7 \mathrm{cP}$ for the hematite suspension. As a matter of fact, it was clearly observed that at a high cd level with red mud, the gas bubbles were hardly lifted to the surface and formed with the suspension a three-phase foam apparently stabilized by the more viscous suspension, exhibiting in addition a lower electrical conductivity because of the gaseous phase contained. As a consequence, the gas bubbles produced at the two electrodes are more difficult to evacuate by Archimedes forces from a suspension of red 
mud than a suspension of hematite. Nevertheless, other phenomena might also explain the large difference in electrolytic performance.

The product of the faradaic efficiency and the cd applied corresponds to the partial cd for Fe deposition; its variation with the applied cd is shown in Figure 3c. The $\log (\mathrm{cd})$ scale has only been used because of the broad cd range investigated. The current consumed for iron deposition increases with the current density until sort of plateau is observed at approx. 45 A.m ${ }^{-2}$, for cd in the range of 80- $150 \mathrm{~A} \cdot \mathrm{m}^{-2}$. In this domain, electrodeposition might be considered due to the cathodic reduction of $\mathrm{Fe}(\mathrm{OH})_{4}^{-}$ions. Applying larger current densities improved the production rate of electrolytic iron, despite the increased evolution rate of hydrogen. For hematite, as reported in the above quoted works, iron deposition is mainly initiated by chemical reduction of hematite adsorbed at the cathode to magnetite in a complex process linked to hydrogen evolution. This step is followed by electrochemical reduction of magnetite via $\mathrm{Fe}(\mathrm{II})$ formation. This mechanism allows to explain the high production rate of iron from hematite (Figure 3c) in accordance with the cited former works. For the case of red mud, a similar trend observed with a fairly constant faradaic efficiency in the range of $20-25 \%$, might be partly explained by a comparable mechanism with adsorbed red mud particles at the cathode; the lower efficiency of iron deposition could be caused by the presence of impurities, either dissolved in the course of the process or present on the surface of solid particles. 

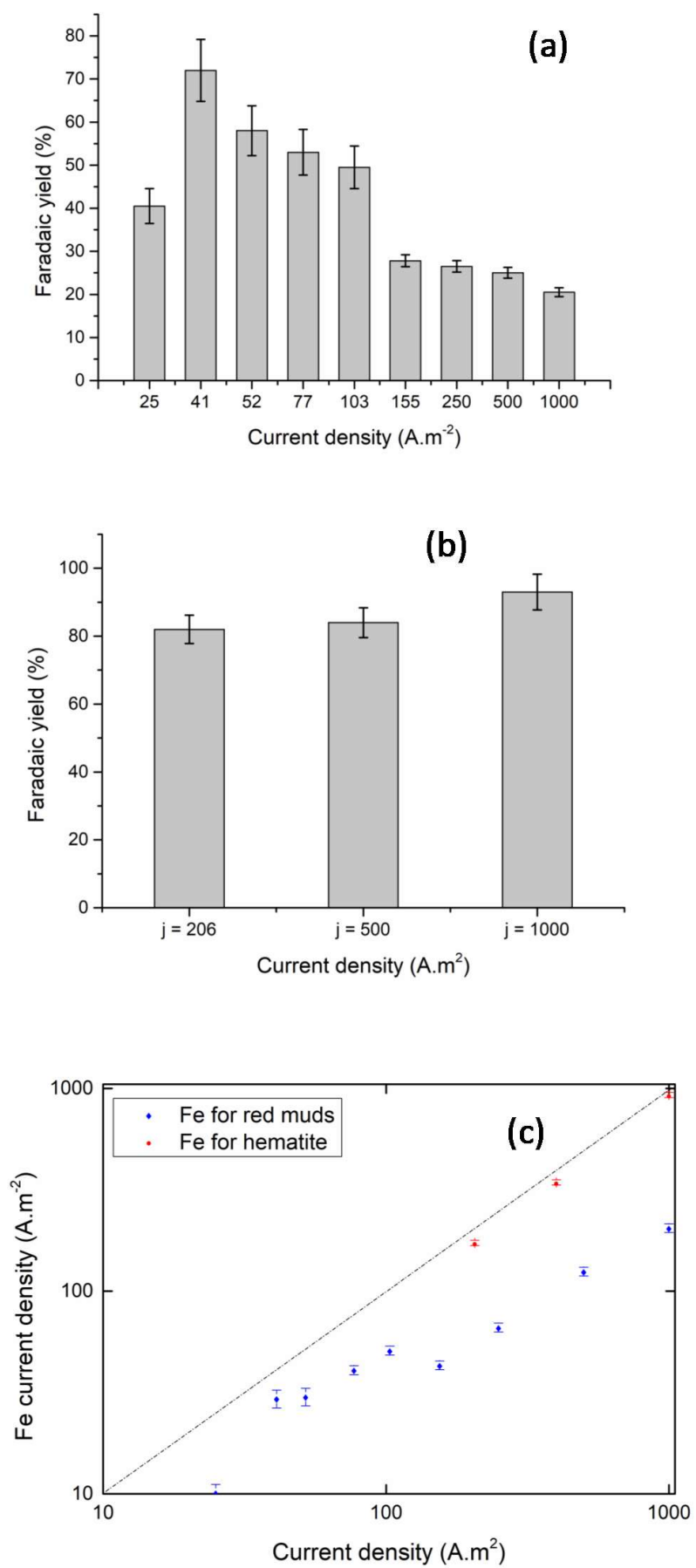

Figure 3: Influence of the current density on faradaic yield using (a) red mud and $12.5 \mathrm{~mol}^{-\mathrm{L}^{-1}}$ $\mathrm{NaOH}$ in a solid/liquid ratio of $1 / 3 \mathrm{~g} / \mathrm{mL}$ for $2 \mathrm{~h}$ at $110^{\circ} \mathrm{C}$; (b) hematite and $12.5 \mathrm{~mol} . \mathrm{L}^{-1}$ $\mathrm{NaOH}$ in a ratio $\mathrm{S}(\mathrm{g}) / \mathrm{L}(\mathrm{mL})=1 / 3$, for $2 \mathrm{~h}$ at $110^{\circ} \mathrm{C}$. (c) Partial current density of iron deposition versus the current density applied. The dotted line is for $100 \%$ faradaic efficiency of iron deposition. Blue symbols are for the red mud, whereas the red ones represent hematite. 


\subsubsection{Influence of the solid/liquid ratio on the faradaic yield}

Several levels of this ratio have been tested to understand the influence of the amount of suspended red mud on faradaic yield, and to find the maximum quantity of red mud to be introduced into the electrochemical cell for high deposition efficiency. The solid/liquid ratio varied from $1 / 10$ to $1 / 2$ $\mathrm{g} / \mathrm{mL}$. The tests were carried out at 41 A.m $\mathrm{m}^{-2}$ corresponding to high faradaic yield.

The results presented in Figure 4 show that for solid/liquid ratios ranging from 1/10 to $1 / 3 \mathrm{~g} / \mathrm{mL}$, the faradaic yield was fairly constant between 75 and $72 \%$. However, with a solid/liquid ratio of $1 / 2 \mathrm{~g} / \mathrm{mL}$, the faradaic yield dropped to $51 \%$. The higher viscosity of the thickest suspension estimated at approx. $10 \mathrm{cP}$ at $110^{\circ} \mathrm{C}$ could be the cause of this lower performance because of a less efficient suspension of the heavy solid from the magnet, a less homogeneous dispersion of the solid particles, and a more stable three-phase foam. A solid/liquid ratio lower or equal to $1 / 3 \mathrm{~g} / \mathrm{mL}$ appears preferable for iron electrochemical deposition.

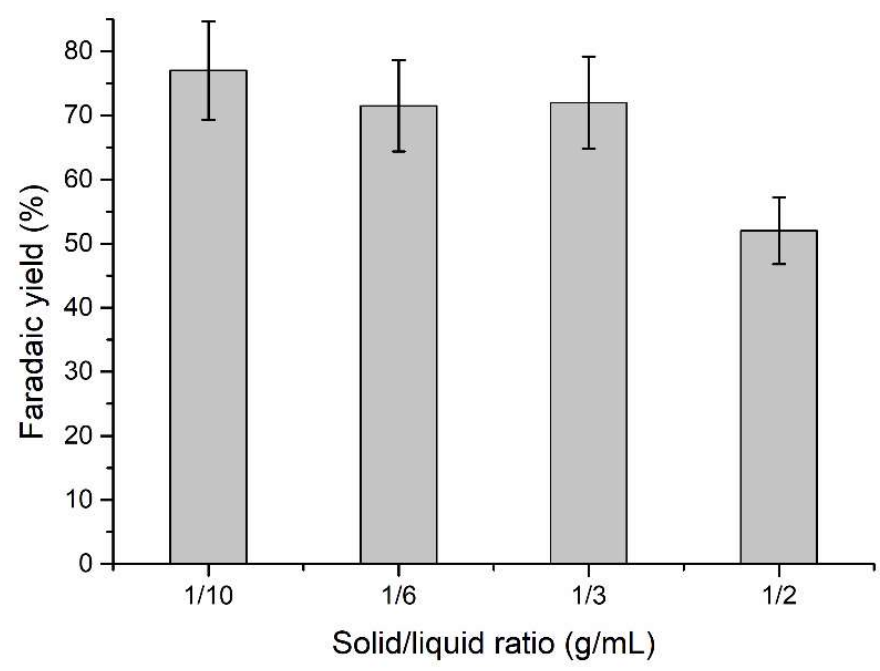

Figure 4: Influence of the solid (red mud)/liquid ratio on faradaic electrodeposition yield with a current density of $41 \mathrm{~A} \cdot \mathrm{m}^{-2}$ at $110{ }^{\circ} \mathrm{C}$ for $2 \mathrm{~h}$. 


\subsubsection{Influence of red mud impurities on faradaic yield}

This section aims to highlight the effect of two different impurities contained in the red muds on the faradaic yield: aluminosilicates present in the red muds can partly dissolve in concentrated alkaline solutions, and the observed larger viscosity of red mud suspensions in comparison to hematite suspensions is likely due to this dissolution (Feynerol, 2018). Moreover, it can be discussed whether dissolved aluminosilicates could inhibit the deposition process. Second, the presence of vanadium, in the form of pentavalent vanadium, has been shown to reduce the current efficiency of particular metals, e.g. gallium (Liu et al., 2012, 2014), by the occurrence of a galvanic couple in the undivided cell, with formation of $\mathrm{V}(\mathrm{II})$ or $\mathrm{V}(\mathrm{III})$ at the cathode and their back oxidation to $\mathrm{V}(\mathrm{V})$ at the anode. All tests with one of the two impurities were carried out for $2 \mathrm{~h}$ with an overall solid/liquid ratio fixed at $1 / 3 \mathrm{~g} / \mathrm{mL}$.

\subsubsection{Influence of aluminosilicates}

To simulate the behavior of red muds, iron electrodeposition tests were carried out by doping commercial hematite with a commercial aluminosilicate $\left(\mathrm{Al}_{2} \mathrm{Si}_{2} \mathrm{O}_{7}, 2 \mathrm{H}_{2} \mathrm{O}\right)$ from $5 \%$ to 30 wt.\%. This aluminosilicate was chosen because it belongs to the cancrinite family, including most aluminosilicates present in red muds. The first tests conducted at $41 \mathrm{~A}^{-\mathrm{m}^{-2}}$ showed the important effect of this impurity (Figure 5a); the faradaic efficiency decreased from $85 \%$ with pure hematite to $63 \%$ with $10 \%$ aluminosilicate, corresponding to a $29 \%$ reduction. In the presence of $30 \%$ $\mathrm{Al}_{2} \mathrm{Si}_{2} \mathrm{O}_{7}, 2 \mathrm{H}_{2} \mathrm{O}$, the yield attained only $36 \%$, i.e. with a $57 \%$ reduction from the value observed with pure hematite. In addition to the high viscosity of the suspension with high aluminosilicate amounts added, it can be supposed that the aluminosilicate salts introduced at high concentrations may partly convert to more complex, little soluble cancrinites, and coat the suspended hematite particles (Feynerol, 2018; Rusch et al., 2010), thus hindering their reactivity. Further tests were 
carried out at a higher current density (Figure 5b). With the blend of $90 \%$ hematite- $10 \%$ aluminosilicates, the current efficiency was decreased by $35 \%$ and $29 \%$ at 400 and 1000 A.m ${ }^{-2}$, respectively, from the levels observed with pure hematite. Nevertheless, at high current density, the current yield exhibited by red muds was shown to be far lower (Fig. $3 \mathrm{a}$ and $5 \mathrm{~b}$ ), being approx. four times lower than the yield obtained with hematite. In this case, in addition to the increased viscosity of the medium, as expressed above, the presence of solid impurities e.g. hydroxycancrinite, perovskite and silicium oxide (Supplementary Material section) on the red mud particle surfaces may hinder the efficiency of their contact on the cathode surface and alter their adsorption, resulting in far poorer yield. Further work would be required to confirm or correct this speculation.

\subsubsection{Influence of vanadium}

Vanadium was introduced in the form of vanadium oxide $\left(\mathrm{V}_{2} \mathrm{O}_{5}\right)$ at 100,500 and $1500 \mathrm{mg} \cdot \mathrm{L}^{-1}$ vanadium into the alkaline solution before introducing hematite (Figure $5 \mathrm{c}$ ). The two low $\mathrm{V}$ contents were tested because of the high reported effect of $\mathrm{V}$ on the selectivity of electrode processes (Liu et al., 2012, 2014; Shirinov et al., 2009), and the highest due to its proximity to the investigated red muds (1490 mg.L $\mathrm{L}^{-1}$, Table S2). Tests performed at $1000 \mathrm{~A} \cdot \mathrm{m}^{-2}$ led to faradaic efficiency little affected by the presence of $\mathrm{V}$ species (data not shown), with values still larger than $77 \%$, even in the presence of $1500 \mathrm{mg} . \mathrm{L}^{-1}$ vanadium. The galvanic couple effect reported for gallium electrodeposition, could not be evidenced here in the electrolytic treatment of hematite. For the red mud investigated, it could not be determined whether vanadium could dissolve in the hot alkaline solution. However, even assuming that vanadium does not dissolve, its low content in comparison to the major impurities on the particle surface, presumably has little effect on their 
reactivity, so it can be considered that the low performance of red muds is not caused by the presence of vanadium oxides.
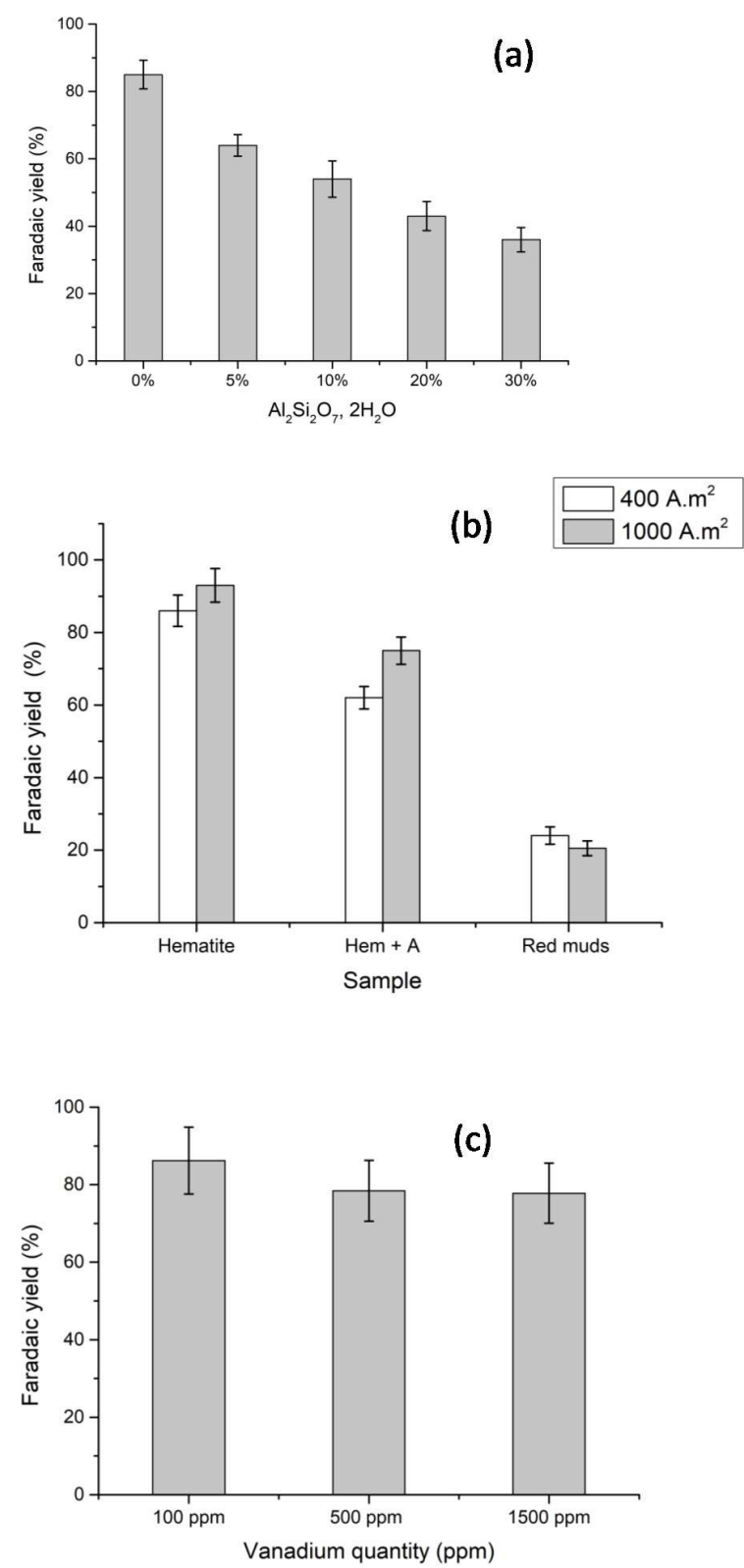

Figure 5: (a) Variation of the faradaic yield with the amount of aluminosilicates (\%wt.) added to the medium at $110^{\circ} \mathrm{C}$ and a $\mathrm{cd}$ of $41 \mathrm{~A}^{-2} \mathrm{~m}^{-2}$ (b) Faradaic yield for hematite, hematite doped with $10 \%$ aluminosilicates $(\mathrm{Hem}+\mathrm{A})$ and red mud slurries at high current densities (400 and $1000 \mathrm{~A} . \mathrm{m}^{-2}$ ). (c) Variation of the faradaic yield with the amount of vanadium added into the medium at $110^{\circ} \mathrm{C}$ and $1000 \mathrm{~A} \cdot \mathrm{m}^{-2}$ 


\subsection{Purity of electrolytic deposits}

Views of the deposit formed are shown in Figure 6. As seen in this image, the electrolytic iron adheres on the graphite cathode.
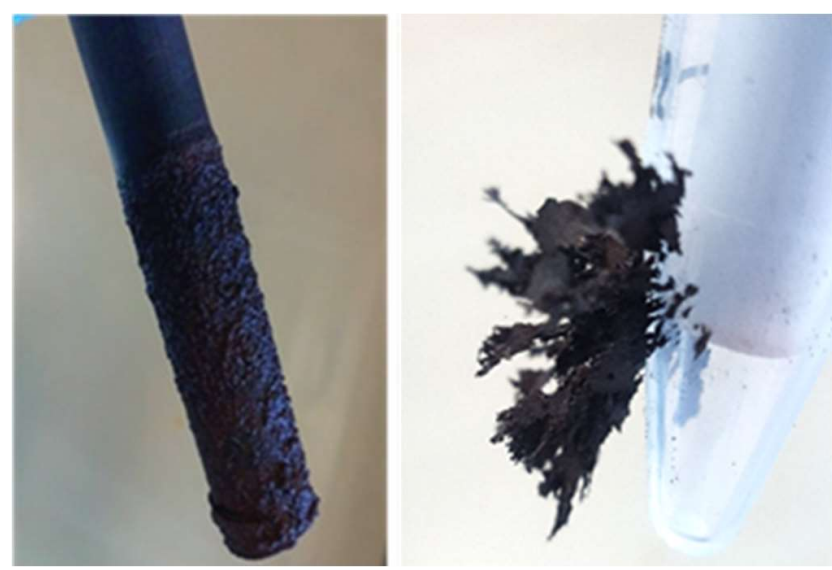

Figure 6: Images of the electrolytic iron deposit on a graphite cathode (left) and the iron deposit adhering to a magnet.

As seen in Table 1, the electrolytic iron deposits produced from the red mud have a purity higher than $97 \%$. This purity value was established by two facts: (i) the amount of Fe analysed in the leachate by ICP-OES matched withing $5 \%$ with the amount of the deposit sample introduced in the leaching vial; (ii) other elements present in the red mud sample which might be contained in the deposit, namely $\mathrm{Al}, \mathrm{As}, \mathrm{Ca}, \mathrm{Na}, \mathrm{Ni}, \mathrm{Si}$ and $\mathrm{Ti}$, were considered in the analysis: only $\mathrm{Al}$ and $\mathrm{Na}$ were detected at quantifiable contents, the other elements being in most cases not detected.

Presence of $\mathrm{Al}$ and $\mathrm{Na}$ can be explained by the fact that they were probably trapped in the iron metal deposit because of its porosity. It should also be noted that the sodium probably originates from the $\mathrm{NaOH}$ solution used and the aluminum comes from the mineral matrices (red mud and commercial hematite).

Table 1: Chemical composition of electrolytic iron deposits (\%wt.) 


\begin{tabular}{|l|c|c|c|}
\hline & $\% \mathrm{Fe}$ & $\% \mathrm{Na}$ & $\% \mathrm{Al}$ \\
\hline $\mathrm{Fe}-$ Hematite & 99.6 & 0.12 & 0.25 \\
\hline $\mathrm{Fe}-$ Red mud & 97.3 & 0.22 & 0.13 \\
\hline
\end{tabular}

Electrolytic iron deposits, obtained from hematite and red muds, were observed by SEM. Figure 7 shows that in both cases, the deposits have a homogeneous morphology with dendrites. The grains are in the form of nodules stacked on top of one another, forming the dendrites. In the case of hematite, iron nodules are several micrometers in size, whereas iron deposits from red muds are more compact with larger dendrites. In general, comparable metal grains were produced, but iron nodules in the case of hematite are longer and thinner than those observed for red mud electrolysis.
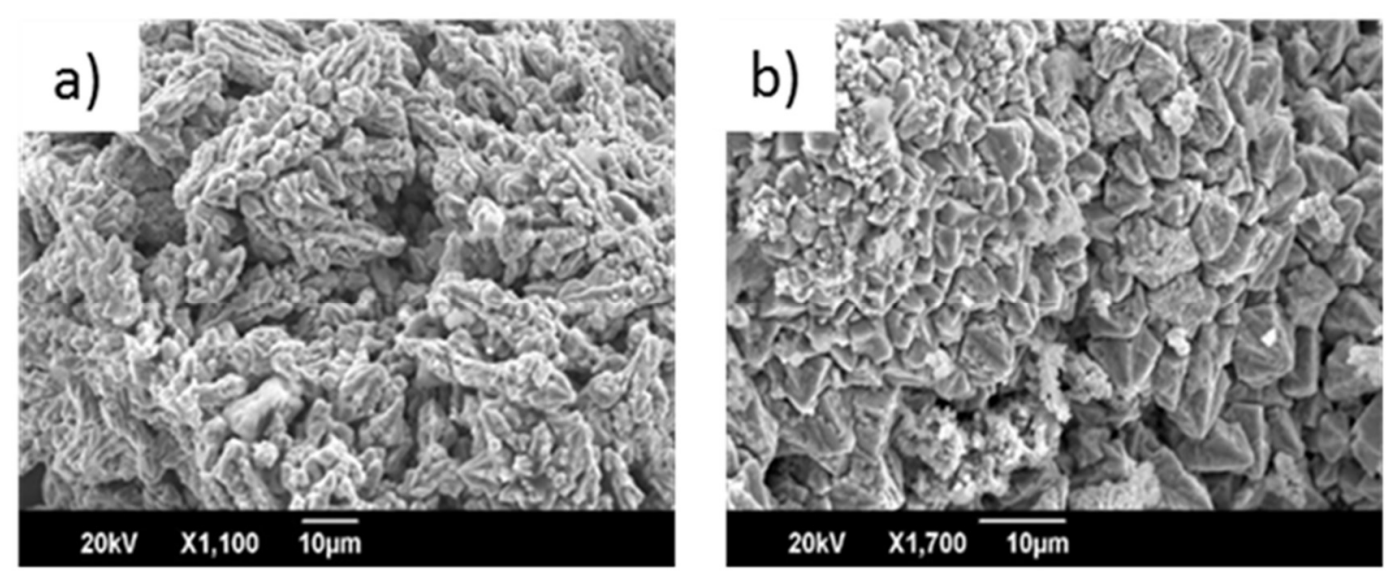

Figure 7: Images of electrolytic iron: a) Fe-hematite and b) Red mud.

X-ray diffraction (Figure 8) shows that the two deposits consist mainly of well-crystallized electrolytic iron. A peak was also detected at 2 theta $=26^{\circ}$, related to graphite oxide and which may originate from the graphite cathode substrate after difficult detachment of the thin deposit. Apart from graphite, no other mineralogical phases could be detected which confirms the purity of the iron deposits obtained from the iron oxide-rich suspensions, in accordance with the above 
results of chemical analysis. This analysis made it possible to assert, in addition to the ICP-OES analysis, that the electrolytic deposit contains approximately $2 \%$ wt. graphite from the cathode substrate during the recovery of the thin, adhering deposit.

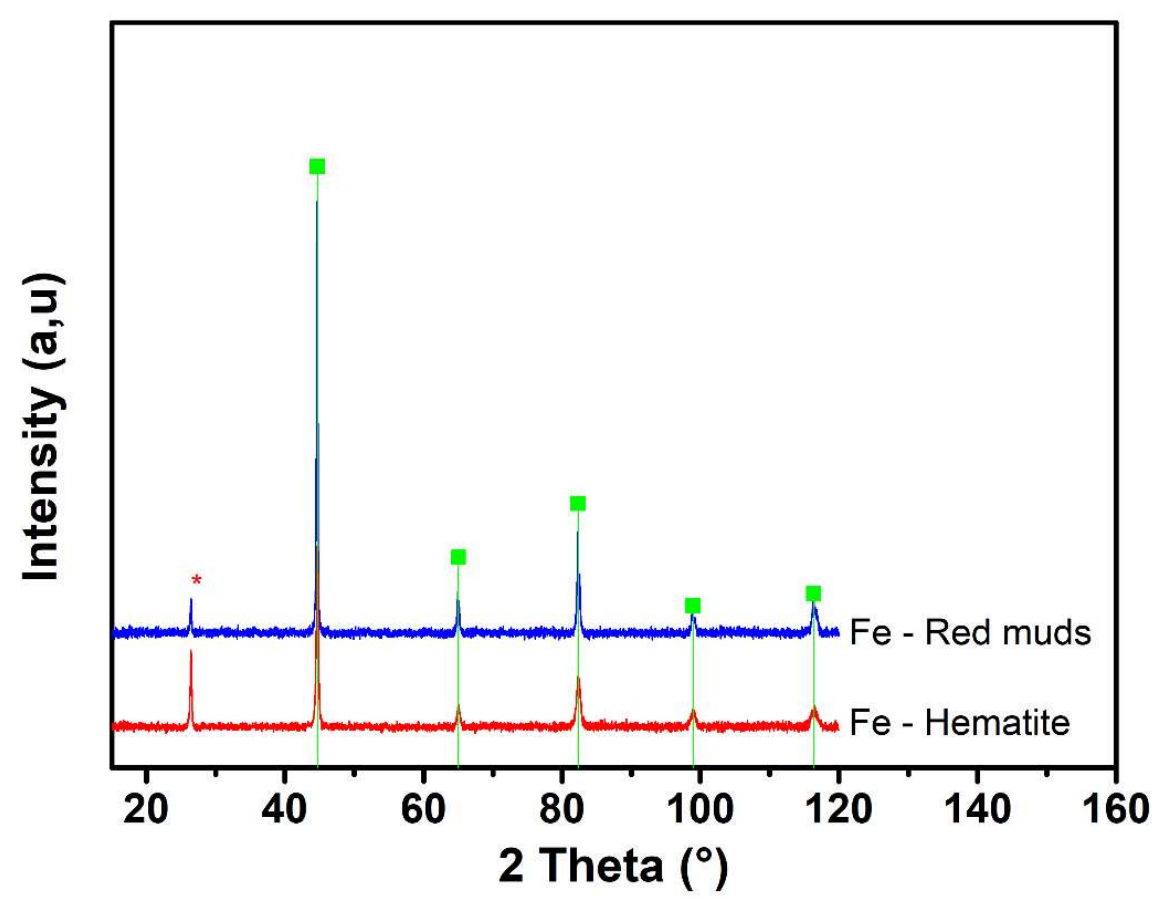

Figure 8: Diffractograms of electrolytic iron deposits: $r e d=\mathrm{Fe}-$ hematite, blue $=\mathrm{Fe}-$ red mud, and $*$ graphite oxide.

\section{Conclusions}

A new alternative route for profitable application of from alumina production waste (red muds) has been suggested and studied: the process consists in reducing the iron oxides contained in an electrolytic cell to produce iron. Red mud samples were first analyzed by different techniques (ICP-AES, SEM, particle size analysis and XRD) to determine their chemical and mineralogical compositions and their particle size distribution. The red mud investigated had a particle size from 0.2 to more than $200 \mu \mathrm{m}$ and mainly contained $\mathrm{Fe}, \mathrm{Si}, \mathrm{Al}, \mathrm{Ti}$, and $\mathrm{Na}$ in the form of hematite, aluminosilicates and perovskite and traces of arsenic and nickel. The voltammograms, carried out 
on suspensions of red mud and commercial hematite in a 12.5 mol. $\mathrm{L}^{-1} \mathrm{NaOH}$ medium at $110{ }^{\circ} \mathrm{C}$, indicated the occurrence of (i) the reduction of ferric ions near $-1.30 \mathrm{~V}$ vs. $\mathrm{Ag} / \mathrm{AgCl}$, and (ii) the reduction of particles at approx. - $1.43 \mathrm{~V}$ vs. $\mathrm{Ag} / \mathrm{AgCl}$, for hematite and red mud. Subsequently, electrodeposition experiments were conducted by chronopotentiometry $\left(12.5\right.$ mol.L $\mathrm{L}^{-1} \mathrm{NaOH}$ at $110^{\circ} \mathrm{C}$ ) with red mud and commercial hematite. The influence of the current density, solid/liquid ratio, and the presence of aluminosilicates and vanadium was studied for high faradaic yield and better understanding. The best faradaic yield was $72 \%$ at 41 A.m ${ }^{-2}$ with red muds. At 1000 A.m ${ }^{-2}$, this yield was only $20.5 \%$ for red muds, whereas it exceeded $80 \%$ for hematite. We suspect that red mud particles do not have the same electrochemical reactivity as commercial hematite, particularly because of the presence of impurities e.g. cancrinite or perovskite, which might affect particle adsorption on the cathode surface, as indicated by emulation tests conducted with hematite upon addition of soluble aluminosilicates or vanadium oxides. The iron obtained had a degree of purity above $97 \%$ for both red mud and hematite.

An in-depth study is currently being conducted on the role of the impurities and/or to propose a pretreatment to eliminate them before the electrodeposition stage. A technical and economic study could be carried out, depending on the pretreatment study mentioned above to evaluate the theoretical economic viability of this process, but larger faradaic yields are first required to make the beneficiation process of potential industrial interest.

\section{Acknowledgements}

This work was supported by the French Ministry of Research and Innovation. The authors would like to thank Pauline Louis, Nicolas Maurice and Steve Pontvianne (LRGP, Nancy, France), Matthieu Gras, Régis Mastretta and Olivier Miollan (Extracthive, Marcoule, France) for their useful contribution in the chemical analysis of solids. 


\section{References}

Allanore, A., Feng, J., Lavelaine, H., Ogle, K., 2010. The adsorption of hematite particles on steel in strongly alkaline electrolyte. J. Electrochem. Soc. 24-30.

https://doi.org/10.1149/1.3273198

Allanore, A., Lavelaine, H., Valentin, G., Birat, J.P., Lapicque, F., 2008. Iron metal production by bulk electrolysis of iron ore particles in aqueous media. J. Electrochem. Soc. 155, E125. https://doi.org/10.1149/1.2952547

Allanore, A., Lavelaine, H., Valentin, G., Birat, J.P., Lapicque, F., 2007. Electrodeposition of metal iron from dissolved species in alkaline media. J. Electrochem. Soc. 154, E187-E193. https://doi.org/10.1149/1.2790285

https://doi.org/10.1149/1.2790285

Bayer, K.J., 1888. Process of obtaining alumina. US382505A.

Béchara, R., Hamadeh, H., Mirgaux, O., Patisson, F., 2018. Optimization of the iron ore direct reduction process through multiscale process modeling. Materials 11. https://doi.org/10.3390/ma11071094

Cusack, P.B., Callery, O., Courtney, R., Ujaczki, É., O’Donoghue, L.M.T., Healy, M.G., 2019. The use of rapid, small-scale column tests to determine the efficiency of bauxite residue as a low-cost adsorbent in the removal of dissolved reactive phosphorus from agricultural waters. J. Environ. Manage. 241, 273-283. https://doi.org/10.1016/j.jenvman.2019.04.042

Feynerol, V., 2018. Treatment of iron ores by alkaline leaching followed by their electrolysis in an alkaline medium ( $\mathrm{PhD}$ dissertation). Université de Lorraine.

Feynerol, V., Lavelaine, H., Marlier, P., Pons, M.-N., Lapicque, F., 2017. Reactivity of suspended iron oxide particles in low temperature alkaline electrolysis. J. Appl. Electrochem. 47, 1339-1350. https://doi.org/10.1007/s10800-017-1127-5

Gu, S., Zou, X., Lu, X., 2014. Electroreduction of Fe2O3 to Fe in strongly alkaline solution. Appl. Mech. Mater. 595, 8-13. https://doi.org/10.4028/www.scientific.net/AMM.595.8

Guo, Y., Gao, J., Xu, H., Zhao, K., Shi, X., 2013. Nuggets production by direct reduction of high iron red mud. J. Iron Steel Res. Int. 20, 24-27. https://doi.org/10.1016/S1006-706X(13)600928

Gupta, V.K., Sharma, S., 2002. Removal of cadmium and zinc from zqueous solutions Using Red Mud. Environ. Sci. Technol. 36, 3612-3617. https://doi.org/10.1021/es020010v

Ju, S., Lu, S., Peng, J., Zhang, L., Srinivasakannan, C., Guo, S., Li, W., 2012. Removal of cadmium from aqueous solutions using red mud granulated with cement. Trans. Nonferrous Met. Soc. China 22, 3140-3146. https://doi.org/10.1016/S1003-6326(12)61766-X 
Li, D., Ding, Y., Li, L., Chang, Z., Rao, Z., Lu, L., 2015. Removal of hexavalent chromium by using red mud activated with cetyltrimethylammonium bromide. Environ. Technol. 36, 1084 1090. https://doi.org/10.1080/09593330.2014.975286

Li, G., Deng, B., Zeng, J., Li, Z., Jiang, T., 2016. Extraction of alumina from the magnetic separation tailings derived from reductive roasting of bauxite residue, in: Williams, E. (Ed.), Light Metals 2016. Springer International Publishing, Cham, pp. 97-102. https://doi.org/10.1007/978-3-319-48251-4_17

Li, Y., Haynes, R.J., Chandrawana, I., Zhou, Y.-F., 2018. Properties of seawater neutralized bauxite residues and changes in chemical, physical and microbial properties induced by additions of gypsum and organic matter. J. Environ. Manage. 223, 489-494. https://doi.org/10.1016/j.jenvman.2018.06.070

Liu, B., Zheng, S., Wang, S., Zhang, Y., Ortega, A., Soo, N., Han, K., 2012. The redox behavior of vanadium in alkaline solutions by cyclic voltammetry method. Electrochimica Acta 76, 262-269. https://doi.org/10.1016/j.electacta.2012.05.008

Liu, C., Li, Y., Luan, Z., Chen, Z., Zhang, Z., Jia, Z., 2007. Adsorption removal of phosphate from aqueous solution by active red mud. J. Environ. Sci. 19, 1166-1170. https://doi.org/10.1016/S1001-0742(07)60190-9

Liu, L., Wang, M.Y., Wang, Z., Zhang, Y., 2014. The influence of impurities on Ga electrowinning: Vanadium and iron. Hydrometallurgy 146, 76-81. https://doi.org/10.1016/j.hydromet.2014.03.009

Mayes, W.M., Burke, I.T., Gomes, H.I., Anton, Á.D., Molnár, M., Feigl, V., Ujaczki, É., 2016. Advances in understanding environmental risks of red mud after the Ajka spill, Hungary. J. Sustain. Metall. 2, 332-343. https://doi.org/10.1007/s40831-016-0050-z

Mišík, M., Burke, I.T., Reismüller, M., Pichler, C., Rainer, B., Mišíková, K., Mayes, W.M., Knasmueller, S., 2014. Red mud a byproduct of aluminum production contains soluble vanadium that causes genotoxic and cytotoxic effects in higher plants. Sci. Total Environ. 493, 883-890. https://doi.org/10.1016/j.scitotenv.2014.06.052

Mohan, D., Pittman, C.U., 2007. Arsenic removal from water/wastewater using adsorbents-A critical review. J. Hazard. Mater. 142, 1-53. https://doi.org/10.1016/j.jhazmat.2007.01.006

Pradhan, J., Das, S.N., Thakur, R.S., 1999. Adsorption of hexavalent chromium from aqueous solution by using activated red mud. J. Colloid Interface Sci. 217, 137-141. https://doi.org/10.1006/jcis.1999.6288

Raspopov, N.A., Korneev, V.P., Averin, V.V., Lainer, Yu.A., Zinoveev, D.V., Dyubanov, V.G., 2013. Reduction of iron oxides during the pyrometallurgical processing of red mud. Russ. Metall. Met. 2013, 33-37. https://doi.org/10.1134/S0036029513010114

Rubinos, D.A., Spagnoli, G., 2019. Assessment of red mud as sorptive landfill liner for the retention of arsenic (V). J. Environ. Manage. 232, 271-285. 
https://doi.org/10.1016/j.jenvman.2018.09.041

Rusch, B., Hanna, K., Humbert, B., 2010. Coating of quartz silica with iron oxides: Characterization and surface reactivity of iron coating phases. Colloids Surf. Physicochem. Eng. Asp. 353, 172-180. https://doi.org/10.1016/j.colsurfa.2009.11.009

Senyuta, A., Panov, A., Suss, A., Layner, Y., 2016. Innovative technology for alumina production from low-grade raw materials, in: Sadler, B.A. (Ed.), Light Metals 2013, The Minerals, Metals \& Materials Series. Springer International Publishing, Cham, pp. 203-208. https://doi.org/10.1007/978-3-319-65136-1_36

Shirinov, E.G., Gasanly, Z.G., Ganbarov, D.M., 2009. Reduction of vanadium from alkaline solutions, Russ. J. Applied Chem. 82, 1230-1233. https://doi.org/10.1134/S1070427209070131

Soner Altundoğan, H., Altundoğan, S., Tümen, F., Bildik, M., 2000. Arsenic removal from aqueous solutions by adsorption on red mud. Waste Manag. 20, 761-767. https://doi.org/10.1016/S0956053X(00)00031-3

Vangelatos, I., Angelopoulos, G.N., Boufounos, D., 2009. Utilization of ferroalumina as raw material in the production of Ordinary Portland Cement. J. Hazard. Mater. 168, 473-478. https://doi.org/10.1016/j.jhazmat.2009.02.049

White, L.C., Paling, E., Singh, P., Zhang, W., 2013. Removal of arsenic by red mud from contaminated waste Water, in: Electrometallurgy and Environmental Hydrometallurgy. John Wiley \& Sons, Ltd, pp. 1951-1957. https://doi.org/10.1002/9781118804407.ch67

Worldsteelprices.com

Yuan, B., Haarberg, G.-M., 2009. Electrowinning of iron in aqueous alkaline solution using rotating risk electrode, Rev de Metallurgie - Cahiers d'Informations techniques, 1, 455-459.

Zhang, H., Lin, C., Sepunaru, L., Batchelor-McAuley, C., Compton, R.G., 2017. Oxygen reduction in alkaline solution at glassy carbon surfaces and the role of adsorbed intermediates. J. Electroanal. Chem. 799, 53-60. https://doi.org/10.1016/j.jelechem.2017.05.037

Zouboulis, A.I., Kydros, K.A., 1993. Use of red mud for toxic metals removal: The case of nickel. J. Chem. Technol. Biotechnol. 58, 95-101. https://doi.org/10.1002/jctb.280580114 